\title{
The Effect of Storytelling and Retelling and Higher Order Thinking on Oral Performance of Elementary Students in English as Foreign Language (EFL) Program: A Pilot Study in Mainland China and Taiwan
}

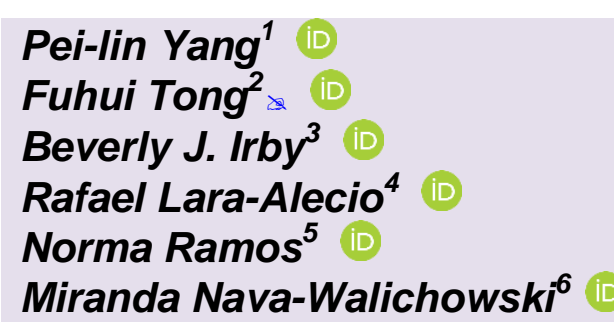

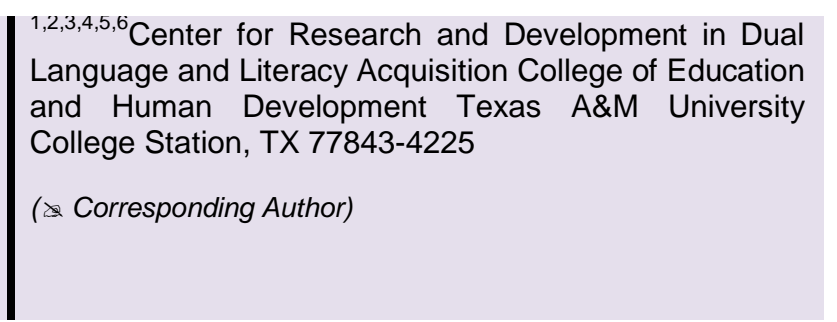

Abstract

The purpose of this pilot study was to evaluate the effect of Story Telling and retelling and higher order thinking for English Language and Literacy Acquisition (STELLA) on the English oral proficiency of elementary students in Mainland China and Taiwan, where English is taught as a foreign language. The 6-week intervention incorporated direct vocabulary instruction, modeling reading, and leveled questioning strategy through storytelling and retelling, and was delivered by certified English teachers who received weekly virtual professional training in two public schools in Mainland China and Taiwan. An English oral vocabulary measure was administered among 10 students in Mainland China and 9 students in Taiwan before and after the intervention. Paired-sample T-tests were conducted to examine the progress from pretest to posttest on the two cohorts, respectively. The results showed a significant improvement on students' oral proficiency at both sites.

Keywords: English oral performance, Story telling/retelling, Elementary school, EFL, Leveled questions.

\section{Contents}

1. Introduction

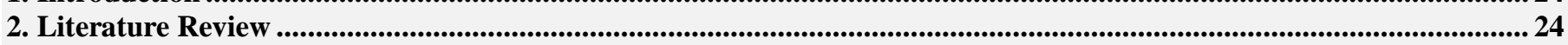

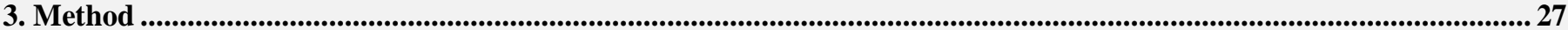

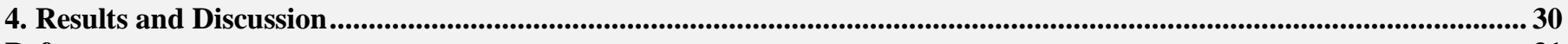

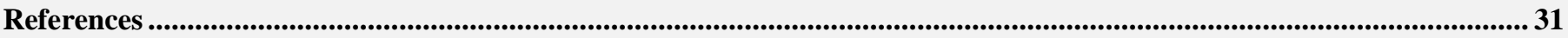

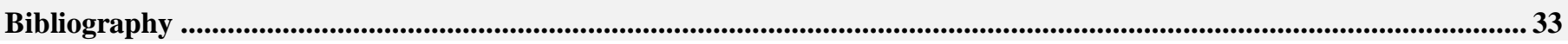

Citation | Pei-lin Yang; Fuhui Tong; Beverly J. Irby; Rafael Lara-Alecio; Norma Ramos; Miranda Nava-Walichowski (2016). The Effect of Storytelling and Retelling and Higher Order Thinking on Oral Performance of Elementary Students in English as Foreign Language (EFL) Program: A Pilot Study in Mainland China and Taiwan. Asian Journal of Education and Training, 2(1): 23-33.

DOI:

Licensed:

Author(s) Contribution:

Funding:

Competing Interests:

Transparency:

Ethical:

Publisher: 10.20448/journal.522/2016.2.1/522.1.23.33 Crossref

This work is licensed under a Creative Commons Attribution 3.0 License $(c)$ EY

All authors contributed to the conception and design of the study.

This study received no specific financial support.

The authors declare that they have no conflict of interests.

The authors confirm that the manuscript is an honest, accurate, and transparent account of the study was reported; that no vital features of the study have been omitted; and that any discrepancies from the study as planned have been explained.

This study follows all ethical practices during writing.

Asian Online Journal Publishing Group 


\section{Introduction}

English, undeniably, has shifted to a global language for communication among people with diverse national, cultural, racial, and linguistic backgrounds in different areas in the world (McKay and Bokhorst-Heng, 2008). Except for the dominant status of English in the notion of the Inner Circle (i.e. the traditional English-speaking countries such as the United States, England, and Canada) and the Outer Circle (i.e. countries where English is not the native tongue but has an institutional role such as India and Malaysia) (Kachru, 1986) the rapid spread of English in the Expanding Circle (i.e. countries where English is used as a medium of international communication such as China and Japan) also has contributed to making English a truly international language (Crystal, 2003). Among the populous regions in the Expanding Circle, Mainland China and Taiwan are the two regions that play important roles by integrating English into the educational curriculum (Chen and Tsai, 2012; Hu and McKay, 2012). Furthermore, in Mainland China and Taiwan, English is widely used and required in many fields, such as internet communication, tourism, mass communication, and domestic and foreign trade. Indeed, power of English also has had a great impact on education policy and instructional practice at all levels (Feng, 2012).

\section{Literature Review}

\subsection{Status of English Language in Mainland China and Taiwan}

Easily observed in mass media or academic articles, learning English has become a passionate movement from preschoolers to adults, not only in educational settings, but also in social environments in some Asian regions. Feng (2012) noted that in the territories called Great China, which, according to him, includes Mainland China, Hong Kong, Taiwan, Macao, and Singapore, people generally perceive the importance of English and have great enthusiasm to engage themselves in learning the language. This phenomenon is also noticed in academic fields and addressed by scholars as an English craze (Jiang, 2003; Hu, 2007;2008) a mania for English (Gil and Adamson, 2011) a national obsession in English or English fever (Chen and Hsieh, 2011) and English-knowing bilingualism or English dominant bilingualism (Tupas, 2011). It was estimated that since the mid-1980s, over 300 million people took an English course in various types of institutions in Mainland China (Honna, 2006). A similar phenomenon has been observed in Taiwan. In fact, it was pointed out that English learning would be a domestic movement in the twenty-first century in Taiwan, with a budget at approximately \$590-738 million U.S. dollars every year listed by the English Language Teaching (ELT) industry, excluding the e-learning industry investing another U.S. \$90 million dollars a year (Chern, 2002).

Further, in Mainland China, English proficiency is not only an academic requirement, it is also tested for job promotions; therefore, having a high level of English proficiency is the key to success for many people (Cheng, 2008). In other words, English proficiency has become the symbol of gatekeeping access, opportunity, status, and power (Hu and Alsagoff, 2010; Hsu, 2015). Similarly, in Taiwan, the importance of English learning was reinforced in Challenge 2008, a 6-year Development Plan (Government Information Office, 2002) by establishing basic English classes for people from all walks of life attempting to promote internationalization.

\subsection{Challenges in English Education in Mainland China and Taiwan}

Even though many Asian people have recognized the importance and practicability of English and have been devoted to learning the language, there are still weaknesses and limitations to the curriculum and instruction in both Mainland China and Taiwan. First, there is a lack of intensity in English instruction in the formal curriculum framework (Chen and Tsai, 2012; Hu and McKay, 2012). The English curriculum with only 2-3 hours each week is called a drip-feed program (Baker, 2006). Pedagogically speaking, another limitation is the use of grammartranslation method which only addresses teaching grammar of the target language (Liu and Shi, 2007). This approach has been criticized as one of the biggest obstacles in learning English, because it pays little attention to students' communicative proficiency (Liu and Shi, 2007). It also has been considered as the major reason that students lose the interest of learning English, because students often get frustrated from memorizing endless grammar rules and vocabulary words (Liu and Shi, 2007). Such an approach is mostly test-driven, with very little emphasis on listening comprehension and oral communication skills. In the research conducted by Pan and Block (2011) 71.5\% of teachers and $56.7 \%$ of students agreed or strongly agreed that the current English education in China is examination oriented, while $69.1 \%$ of teachers and $69.3 \%$ of students agreed that current English examinations are mostly about the assessment of English grammar. In Taiwan, the aim of English instruction also has been to help students pass the entrance examinations to senior high schools and universities ( $\mathrm{Su}, 2000)$. Even at college level, the focus of English curriculum is still reading and grammar translation; mainly in reading and translating anthologies of literary works (Chern, 2002). In Mainland China and Taiwan, the pressure from parents' expectations and passing various types of examinations caused insufficient instruction in developing students' communicative English proficiency (Chen and Tsai, 2012; Zhang, 2012). These weaknesses which have existed in the mainstream schools for many years, along with limited exposure to English in a non-English dominant society can be an obstacle to the development of students' English literacy skills, especially the oral language skills.

\subsection{The Significance of Oral Language Proficiency}

Although the lack of opportunity to develop oral language proficiency appears to be the biggest challenge for English instruction in an English as foreign language (EFL) environment, it is a crucial factor for successful language acquisition (Slavin and Cheung, 2005). Among the four literacy domains - listening, speaking, reading, and writing, the latter two have been traditionally considered as academic domains; however, the first two domains are, in fact, as important as reading and writing (Gibbons, 2002).

For English language learners (ELLs), expressive oral proficiency can play a critical role in second language acquisition. Smith and Ellis (2003) pointed out that the oral competence in the second language for ELLs can be an indicator for other subsequent literacy skills in that language, because higher level of oral proficiency is associated 
with increased listening and speaking vocabulary, which can lead to reading and writing vocabulary through direct and structured instruction (Reese et al., 2000; Miller et al., 2006). Gambrell et al. (1991) reinforced the positive correlation between oral proficiency and reading skills, and reported that especially for young ELLs, oral language competence is a critical factor to impact their academic performance. According to the researchers, children subconsciously acquire oral language proficiency at young age, approximately from birth to age 5 then increasingly acquire phonology, vocabulary, grammar, semantics, and pragmatics in their native language (Ovando and Collier, 1998). Furthermore, a child will be very likely to encounter reading problems if that child is deprived of a literacypromoting environment (Snow et al., 1998). Therefore, many English learning programs put emphasis on children's oral development in their early grades until the students achieve a specified level of language proficiency (Saunders and O'Brien, 2006).

\subsection{Critical Components to Facilitate Oral Language Proficiency}

In 1996, Kame'enui, Adams, and Lyon indicated that the academic underachievement of ELLs could be a result of reading problems related to comprehension skills, vocabulary knowledge, and content structure of the target language. Seven years later, August (2003) pointed out that to enhance English oral proficiency, the three literacy skills that should be addressed are vocabulary, grammar, and comprehension. McVey (2007) also indicated that along with correct grammar, vocabulary knowledge can promote the communication ability of ELLs, both verbally and in writing.

Due to the limited instructional time in classroom and exposure outside school settings, it is extraordinarily important for learners in EFL programs to receive effective vocabulary instruction in order to facilitate oral language development. Among various ways to promote vocabulary competence for ELLs, the most effective is to teach through direct instruction (Kamil, 2004) and as indicated by Roberts (2008) among different strategies of direct instruction, story reading can be used as an effective tool to increase students' vocabulary, especially through repeated reading. Even in a native English-speaking environment, story reading has been considered as a popular approach in school and family environments.

Other than appropriate instruction, one of the important assignments for educators of ELLs is the appropriate and periodical, ongoing assessment of the literacy development, because it serves as the indicator of the efficacy of curriculum and instruction. To ensure the academic success by developing English language literacy, Tong et al. (2008) recommended when applying explicit and systematic English-as-a-second language instruction, structured story retell can be used as an effective pedagogical tool, because it provides modeling of language use, intonation, and prosody.

\subsection{The Effect of the Storytelling on Language Learning}

Storytelling and L1. Sharing stories has been suggested to be effective in language learning for young children and often incorporated in children literature and early childhood texts (Raines and Isbell, 1994). Sobol (1992) described that in a traditional oral storytelling event, the story text was the primary references of the communication expressed in its emergent, imaginative substance and the relationship between listeners and tellers in interactive performance. Therefore, the words in the text are not memorized but utilized through spontaneous performance assisted by the audience participation and interaction (Isbell et al., 2004). Different from story reading, in which listeners might receive the information passively, storytelling required audience participation. During the storytelling process, the audiences are encouraged to give repetitive phrases or refrains or even to suggest variations in some certain free story components. These elements in the storytelling strategy were therefore described as a type of twoway co-creative communication (Roney, 1996).

It has been recognized that storytelling can have important practical implications in educational settings, especially in primary school level (Collins, 1999). As far back in 1982, Ferrell and Nessell argued that storytelling could enhance students' vocabulary acquisition, reading fluency and story recall proficiency. Peck (1989) also found that, in addition to facilitating reading and listening comprehension, telling stories in classroom also improved students' written and oral language development. In the study conducted by Isbell et al. (2004) the students who received a 12-week storytelling intervention had a significant better performance in providing the story setting, the moral, a formal ending and remembering the story characters, which lead to a conclusion that storytelling enhanced the imaginative recollection of the story with verbal development in the story transmission. More researchers have found positive results on the effect of storytelling strategy. Lever and Sénéchal (2011) determined that children who received dialogic story reading intervention performed better in narrative ability and expressive vocabulary knowledge. Massey (2013) also concluded that through interactive storytelling incorporated scaffolding instruction help young children promote their oral language development. Furthermore, Mokhtar et al. (2011) identified the positive effects of storytelling on students' communication ability. Their findings showed that with storytelling instruction, students were more able to associate meanings with words and to use certain words and phrases orally.

Storytelling and ESL/EFL. Compared with studies on monolingual English-speaking children, researches regarding the effect of storytelling on ELLs are limited. Collins (2010) implemented a three-week storytelling intervention with direct and rich vocabulary instruction on ELL preschoolers. The results of her study showed a significant contribution to sophisticated vocabulary acquisition from a storytelling context, and vocabulary knowledge is one critical component to promote the oral communication ability of ELLs (McVey, 2007). Dockrell et al. (2010) also found a positive effect of the storytelling intervention on the expressive language ability of young ELLs.

For the learners who learn English as a foreign language in Asia, it was reported that storytelling with enriched illustrations and repeated structure and instruction could improve their vocabulary knowledge (Elley, 1989; Malderez, 2010). For example, Chien and Huang (2000) argued that utilizing storybooks with interactive instructional application was effective to build the oral ability and improve the literacy development of EFL learners. In the study conducted by Moon and Maeng (2012) 20 fourth-grade students in Korea received a 10-week 
storytelling intervention and a significant improvement in reading comprehension in English of the participants was observed. Similarly, Hsu (2015) implemented a six-week storytelling intervention on 21 bilingual kindergarteners in Taiwan and found positive effect of the strategy in triggering students' learning interests and lowering their learning anxiety. However, the studies mentioned above only focused on one single component -- storytelling. STELLA, instead, is a comprehensive intervention incorporated with storytelling, retelling, direct vocabulary instruction, ESL strategies and higher-order questioning skills. With the implementation of STELLA, we seek to examine the effect of these combined instructional practices on English vocabulary learning in EFL settings in Asia.

\subsection{The Effect of Story Retelling Strategy on Oral Language Proficiency}

The importance and function of story retelling was first addressed and reported almost four decades ago. Hansen (1978) declared that story retelling could provide teachers with an alternative to assessing students' abilities and for retrieving and obtaining information about students' comprehension. According to Morrow (1996) story retelling is a post-reading and post-listening recall activity for students to express what they have learned and discussed previously. Slavin and Madden (1999) further defined story retelling as the summary of the main points of the story made by students and shared with their peers after reading and discussing the story. Lara-Alecio et al. (2015) defined storytelling and retelling as a teaching strategy that engages students prior to, during, and after story read aloud with storytelling/retelling. Teaching strategies for their STELLA model also include asking leveled questions, particularly higher order questions, which are integrated during the activities (such questions are strategically placed within the lesson). They indicated the overall purpose of STELLA is to increase the pre-during-and-post listening and reading opportunities for ELLs to acquire and practice oral language skills.

It has been found that story retelling can offer students opportunities to orally construct the story, which can be a challenge for ELLs (Snow, 2002). In addition to the current knowledge, for ELLs to retell the stories, they also need to connect their prior knowledge with the new input; therefore, to accomplish story retelling, listeners or readers need to demonstrate what they remember or understand according to the comprehension they built (Gibson et al., 2003).

Story telling/retelling serves as not only an effective instructional strategy for students' literacy development but also a valuable tool to enhance and evaluate their learning process. For teachers, structured story retelling via wellplanned and scripted lessons can utilize research-based learning strategies can provide an access to understanding the process of students' oral composition and reconstruction (Lara-Alecio et al., 2006). It is also the reason why story retelling is preferred over other comprehension-like assessment (Roberts et al., 2005). For students, story retelling requires active engagement and organization of thoughts and provides students with motivation and a critical gateway to a higher level of thinking and comprehension skills (Irby et al., 2008). Followed by the story content discussion, in which the teacher acts as a facilitator of students' expressive language, story retelling creates an environment where students can be the center of learning by demonstrating their comprehension and oral skills while elaborating their ideas and thoughts at the same time (Anderson and Roit, 1998). The STELLA strategy of story retell makes students focus on reading the story as a whole instead of segmental passages and the focus provides readers with the framework to improve comprehension (Irby et al., 2008). Gambrell et al. (1991) conducted a study on 48 fourth grade participants to investigate the effect of story retelling on students' reading comprehension. The result of the research showed that the readers who practiced recalling remembered more propositions and story structure and improved in free and cued recall retelling. This study also showed a strong positive relationship between oral language and reading comprehension.

Having students to retell a passage of a story is also an effective pedagogical tool to monitor the listening and reading comprehension of ELLs. Assessment of comprehension of ELLs is always a great challenge to teachers and educators because the literacy development of ELLs might not be sufficient enough to express their understanding of the curriculum. Therefore, the curriculum-based measurement may provide more valuable information than the norm-referenced assessment because it can provide teachers with closer and continuous monitoring of students' comprehension (Domínguez and Shapiro, 2007). Story retelling is a strategy that can be processed in different formats, including summarizing the story individually, group discussion and peer sharing in big or small groups. According to Saenz et al. (2005) story retelling can also be considered as part of peer-assisted instruction, and such is employed in STELLA.

In conclusion, story retelling has been identified as an effective instructional strategy to facilitate ELL's oral proficiency, which is considered as a critical element in second language acquisition because it is closely related to other literacy skills that will impact the academic performance of ELLs (Smith and Ellis, 2003; Slavin and Cheung, 2005; Saunders and O'Brien, 2006). However, these studies have focused on the development of ELLs in an Englishspeaking environment, and we found limited research conducted in EFL settings. Therefore, the main purpose of this study was to determine the effectiveness of the storytelling and retelling on the English oral proficiency of EFL students in a non-English speaking environment.

\subsection{Significance and Purpose of the Study}

The main goal of teachers and school administrators is to help students pass various types of English examinations because of the test-oriented educational system and parents' expectations in Mainland China and Taiwan (Chen and Tsai, 2012; Zhang, 2012). Unfortunately, the lack of sufficient and effective instructional approach to enhance English communicative proficiency results in the fact that students who pass high level traditional English tests still cannot communicate fluently in English (Chen and Tsai, 2012; Zhang, 2012). In order to address such limitation, innovative teaching strategies can be a critical solution to the problem. The intervention, Story Telling and retelling and higher order thinking for English Language and Literacy Acquisition (Irby et al., 2004) has been found to be an effective intervention to promote oral proficiency and literacy skills for ELLs in English speaking environment (Irby et al., 2004; Quiros, 2008; Tong et al., 2008; Quiros et al., 2012) but it has not been tested in non-English speaking areas. This current study is the first to include students in an EFL environment in which English is not the main communication medium. 
Therefore, the purpose of this study was to evaluate the effect of STELLA on the English oral proficiency of students in EFL settings in Asia. STELLA is a structured story-reading/telling and retelling and higher order thinking instructional intervention which has already been found to be effective in facilitating oral language, vocabulary, comprehension, and critical/higher level thinking skills of ELLs in the United States (Quiros et al., 2012). The basic element of the intervention is story reading, telling, and retelling; direct vocabulary instruction, and integration of higher-order thinking questions strategies. We explored the effect of STELLA on the oral proficiency of students in two elementary schools in Asia, one in mainland China and one in Taiwan, where English is not the main communicative tool in the society. By implementing this intervention in Asia, we sought to answer the following research question: Is students' English oral proficiency significantly improved after receiving STELLA intervention in EFL settings in Asia?

\section{Method}

\subsection{Context and Participants}

This study was conducted in two elementary schools, one in Mainland China and one in Taiwan. The school in Mainland China was included because the researchers knew the Dean of the school of education at a local university. He had worked with the school on various projects and introduced the team to the school principal. The experimental site in Mainland China is a public primary school located in an urban area with approximately 2,000 students from grades 1 to 6 . The intervention was implemented in a fourth-grade classroom with 43 students with even gender proportions. Most students come from families with medium to high social economic status. All these students received a 40-minute English instruction each day for 5 days a week outside their English curriculum block. Although the whole class received the intervention, 10 nine-year-old students (five high performers and five low performers as determined by the teacher) were randomly selected to participate in the assessment.

The school in Taiwan is a small public primary school in the rural area. We were introduced to this school by one of the researchers who is from Taiwan and who had worked previously at this school. There are only 91 students from grades 1 to 6 . The class in which the intervention was conducted is a third-grade classroom with 11 eight-yearold students, who come from diverse family backgrounds ranging from low to high social economic status. The 45minute intervention was delivered in one of the formal English classes of the week and also conducted in extra time slots during the day. The intervention was also conducted to the whole class of 11 students, nine of which gave the consent to participate in the assessments.

At both sites, Mandarin Chinese is the official and major language spoken at home, while English is taught as a foreign language in school settings. The two teacher participants are each certified with more than 7 years of English teaching experiences.

\subsection{Research Design}

The main purpose of this study is to evaluate the effect of STELLA on the oral proficiency development among elementary students in EFL settings. The same instructional intervention was first implemented in the school in Mainland China, followed by the school in Taiwan. Each intervention was for 40-45 minutes each day for 5 days a week and lasted for 6 weeks. The weekly intervention was based on the storybook selected by the curriculum experts and 6 stories were introduced during the whole intervention.

The English subject is incorporated into the formal curriculum in both Mainland China and Taiwan. In Mainland China, students have an English class session of 40-45 minutes each day while the students in Taiwan only have two 40-minute English sessions every week.

A curriculum-based vocabulary fluency measure was conducted to 10 randomly selected participants in China and nine randomly selected participants in Taiwan by the English teachers before and after the intervention. The orally constructed sentences were recorded by the English teachers who were trained by the researchers and scored by the researchers. Sentences were recorded prior to the intervention and after the intervention and were used as pretest and posttest scores for data analysis.

\subsection{Instructional Intervention: STELLA}

A 40-45 minute STELLA lesson was implemented each day, 5 days a week, for a total length of 6 weeks at both sites. The teachers received one-hour training via an online meeting tool every week provided by a curriculum expert, who is also in charge of the modification of STELLA curriculum to be implemented in elementary schools in the United States. The training included detailed information about picture description, story reading, vocabulary instruction, ESL strategy, and questioning strategy to be delivered to the students in the upcoming lesson. Each week there was a story, for a total of six stories in this study.

During the entire intervention, English was the major language and students' native language was used for clarification when necessary. Six target stories were selected before the training according to the complexity of the story structure and content and were implemented with the scripts in sequence during the 6-week period. With the scripted lesson plans, the teacher provided direct vocabulary instruction, story reading and structured higher-order thinking questions, scaffold interactive discussion among peers and story retelling from students. An example of the 5-day lesson in the first week is described as follows and is depicted in Figure 1. 


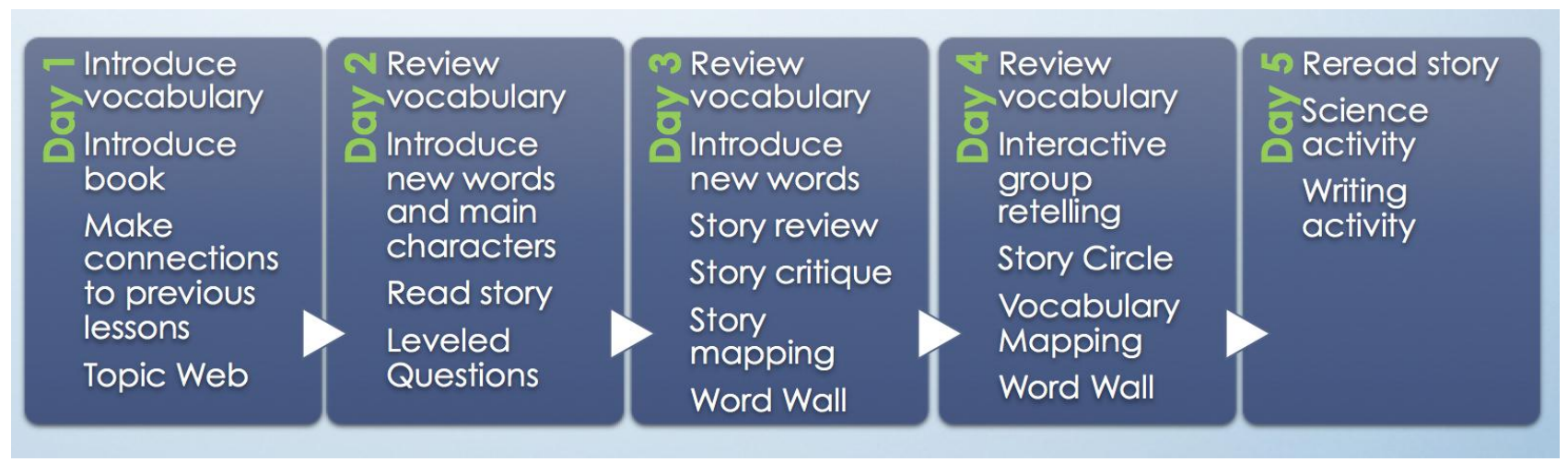

Source: Lara-Alecio et al. (2016).

Figure-1. STELLA 5-day lesson.

On Day 1, instead of reading the text of the story, the teacher first introduced the author and the illustrator to motivate students' imagination and curiosity before leading students to read the story text, then target vocabulary was directly introduced. A brief introduction of the story content was discussed at the end so students could have preparation and expectation towards the following lesson next day.

On Day 2, the target vocabulary was firstly reviewed with explicit instruction, teacher's modeling and picture cards to establish connection with the previous knowledge. After introducing the main characters by using leveled and higher-order thinking questioning strategies, the teacher would begin to read the whole story text to the students. In this process, after reading the page with the target vocabulary, the teacher would stop to ask students leveled questions to increase comprehension. The information activated on Day 1 facilitated students' understanding of the story in the target language. These teacher-led questioning and answering could assist students in analyzing the whole text into bits of information, thus making connections between text and illustration. This strategy guided students in the comprehension process showing that illustrations convey a message apart from the text.

On Day 3, the teacher reviewed the vocabulary and story content by showing the picture cards and rereading the text. During the reading aloud, the students were invited to recall the target vocabulary, the title, main characters and the setting. Then the students would do the story critique utilizing their literacy skills under the scaffolding of the teacher in an encouraging and risk-free environment.

On Day 4, the teacher led students to review the story vocabulary as how they were related to the story plot with questioning strategy. Then the students were invited to recall the title, the author and illustrator, and the characters of the story. After the review, the students would be asked to do interactive group retelling by rereading the story text with the vocabulary covered by the teacher so they can fill in blanks by saying them aloud together.

On Day 5, students would review all vocabulary, repeat interactive group retelling, and reread the whole story. There was a brief writing activity that was also incorporated on Day 5.

The number of target vocabulary and the complexity of the story plot, structure, and text would increase as the intervention proceeds with the remaining stories. The degree of the difficulty of the students' tasks would also increase accordingly. For example, there were only three target words in the first story but the sixth story had seven words and six of them were compound. At the end of the last week intervention, the students were asked to review by using vocabulary mapping and to do a science project by writing a complete passage using academic sequence adverbs. During the intervention, except reviewing the content introduced in the previous class, the teacher gradually provide explicit vocabulary instruction, storytelling and retelling, description of plots, characters and context of the story, along with structured questioning strategies; and the students were involved in guided literacy instruction, interactive peer discussion, reading and retelling the story and answering higher-order thinking questions.

Vocabulary instruction. Direct vocabulary instruction is the core of the STELLA curriculum in order to facilitate the vocabulary knowledge and comprehension of learners. The target vocabulary was embedded in the story contexts and introduced to the students with graphic organizers, vocabulary cards, and word walls. All the visual aids were applied as scaffolding for students to enhance vocabulary acquisition and comprehension of the text. Authentic pictures of the target vocabulary with the explicit definition were presented on the vocabulary cards as depicted in Figure 2. Review of the learned vocabulary was constantly addressed in the five-day lesson to provide students with repeated exposure to reinforce students' memory of the target vocabulary. A word wall composed of different word cards was also utilized in this phase to assist students for word review and provide a scaffolding for spelling check when students began to get engaged in writing activities or sentence construction. 


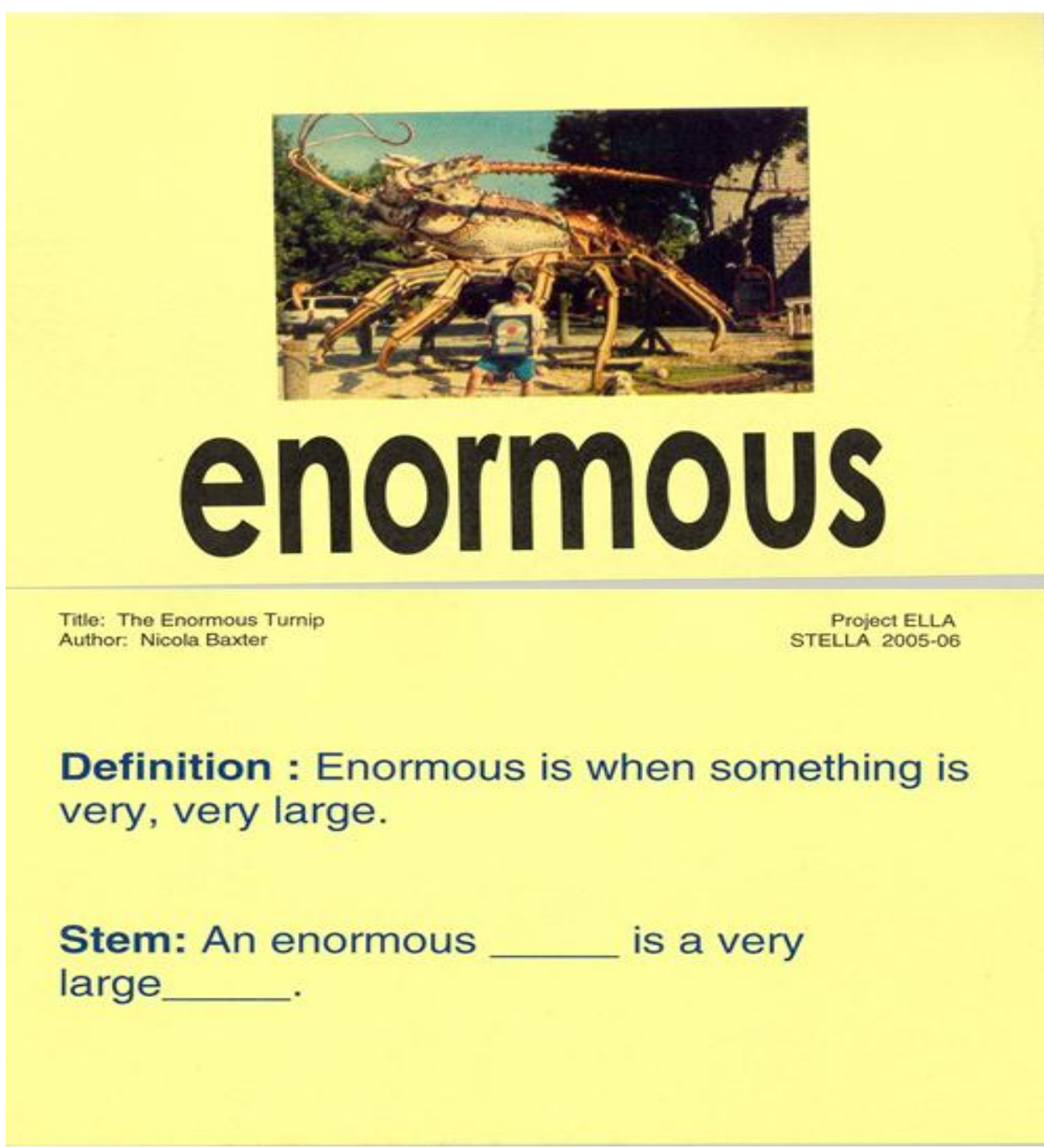

Source: Irby et al. (2008). Used with permission.

Higher-order thinking questioning strategy. Unlike low-level questions, higher-order thinking questions demand learners to elaborate and process information to a deeper level by exposing them to a novel problem-solving scenario (Fenesi et al., 2014). In STELLA curriculum, higher-order thinking questions were addressed to enhance students' comprehension in an interactive process. Open questions like "Explain what is happening on these two pages?" were asked to stimulate students' motivation and encourage them to answer in complete sentences. Along with the vocabulary and reading instruction, questions such as "How would you feel if you saw a tadpole wriggling out of its jelly shell" were asked for students to elaborate and extend the story context to their real life experiences. In the review phase of the lesson, teachers asked questions like "What are some of the problems that you could encounter in a pond?" to reinforce students' current knowledge and elaborate to a deeper level.

ESL strategies. ESL strategies can enhance the learning process of English language learners and also help them to reduce the anxiety level when learning a new language (Quiros, 2008). Instructional activities applied in STELLA supported the implementation of the curriculum, such as interactive read aloud, group discussion, graphic organizers, and sentence stems. They all require large amount of language practice during the lesson, so students can take an active role during learning. The purpose of applying effective ESL strategies into STELLA instruction was to assist students to connect their prior knowledge to the current content as well as facilitate the language learning process in academic settings.

Teacher training. To ensure the fidelity of intervention and testing, professional trainings were provided by a curriculum expert to the teachers at both sites during the whole period of the intervention. All the material and storybooks were delivered to both sites before the intervention and all professional training sessions were conducted through virtual access, such as GoToMeeting software. The virtual trainings were held weekly during the intervention to discuss students' progress and review the scripts and lesson plans for the upcoming week. The trainings provided to the teachers covered all the major components in STELLA. In addition to explaining the scripted lesson plans page by page, the curriculum expert also provided training in oral language and vocabulary development, leveled questions, ESL strategies and suggestions in responsive to teachers' inquiries.

\subsection{Assessment and Scoring}

In this study, a curriculum-based assessment, STELLA Oral Vocabulary Measure (Figure 3), was used to assess English oral proficiency of the participants, who were given 31 target vocabulary words that were included in the six stories, and were asked to orally produce a complete sentence with each word. The same test was given before and after the intervention by the English teachers, who were trained by the researchers. The participants were tested individually and given directions and practice before the test. During the test, if a student remained silent for over seven seconds, s/he would receive a score of zero. If a student could initiate a sentence within seven seconds, the tester would wait until the student finished and then write down the spoken sentence on the measure record. See 
Figure 3 for a list of vocabulary used in the current study. If a student could not respond for five consecutive words, the test would be discontinued.

After the oral sentences documented by the teachers were collected, four trained graduates majoring in education rated these oral production according to the rubric of Semantic + Syntactic Scoring System (S4) (Walichowski, 2009). S4 was created and developed specifically for STELLA Oral Vocabulary Measure. With this rubric, teachers were able to use the target vocabulary included in the curriculum to assess the word knowledge, sentence structure and oral proficiency of each individual student. The scores of the system range from 0 to 4 according to (a) the structure of the sentence, (b) the associated knowledge with the target word, (c) the context where the sentence is set, and (d) the elaboration of the syntactic sentence structure. The inter-rater reliability among the four raters reached over .95 .

\begin{tabular}{|c|c|c|c|}
\hline & Word (单词) & Sentence(句子) & Time(时间) \\
\hline 1 & feathers & & \\
\hline 2 & fur & & \\
\hline 3 & llama & & \\
\hline 4 & journey & & \\
\hline 5 & munch & & \\
\hline 6 & boulder & & \\
\hline 7 & swooped & & \\
\hline 8 & rule & & \\
\hline 9 & obey & & \\
\hline 10 & gentle & & \\
\hline 11 & stranger & & \\
\hline 12 & outlaw & & \\
\hline 13 & damage & & \\
\hline 14 & hairy & & \\
\hline 15 & grip & & \\
\hline 16 & burst & & \\
\hline 17 & wriggle & & \\
\hline 18 & crumpled & & \\
\hline 19 & attack & & \\
\hline 20 & discover & & \\
\hline 21 & gingerly & & \\
\hline 22 & snug & & \\
\hline 23 & ocean & & \\
\hline 24 & whisper & & \\
\hline 25 & tadpole & & \\
\hline 26 & surface & & \\
\hline 27 & disappear(ed) & & \\
\hline 28 & pond & & \\
\hline 29 & peering & & \\
\hline 30 & scooped & & \\
\hline 31 & frogspawn & & \\
\hline
\end{tabular}

Figure-3. STELLA oral vocabulary measure record example from the current study

\subsection{Data Collection and Analysis}

At both sites in Mainland China and Taiwan, the curriculum-based vocabulary measure was administered by the teachers before and after the intervention. An initial meeting was held prior to the testing so that the teachers could be trained to administer the assessment. At the Mainland China site, the intervention was delivered in the fall semester in the 2013-14 school year with the post-test completed in the end of January of 2014. At the Taiwan site, the intervention was conducted in the fall semester in the 2013-14 school year with the post-test completed by the end of May of 2014. To determine if there was a significant difference between the pre-test and post-test, a paired sample $t$-test was conducted on the students' scores at each site, respectively.

\section{Results and Discussion}

The purpose of this study was to investigate the effect of STELLA on the English oral proficiency of the students in EFL settings in Asia. To achieve this purpose, a 6-week intervention of STELLA was implemented among elementary students in two public schools in China and Taiwan, in which English is not the major communicative language in the society. A curriculum-based vocabulary fluency measure was used before and after the intervention to examine students' growth in English oral proficiency.

The research question for this study was: Is students' English oral proficiency significantly improved after the intervention at both sites? Descriptive statistics of the STELLA Oral Vocabulary Measure are presented in Table 1. As indicated to compare the pretest and posttest of the same group, we conducted a paired sample $t$-test for each site, respectively. The analysis yielded a statistically significant difference from pretest to posttest with a large effect size in the form of Cohen's $d$, on students' English oral performance as indicated in Table 1. 
Table-1. Descriptive and Inferential Statistics of STELLA Oral Vocabulary Measure

\begin{tabular}{|c|c|c|c|c|c|c|}
\hline \multirow[b]{2}{*}{ Site } & \multicolumn{2}{|c|}{ Pretest } & \multicolumn{2}{|c|}{ Posttest } & \multirow[b]{2}{*}{$p$} & \multirow[b]{2}{*}{ Cohen's $d$} \\
\hline & Mean & Std. Deviation & Mean & Std. Deviation & & \\
\hline Mainland China & .0509 & .36955 & 1.5963 & 1.47642 & $<.001$ & .9 \\
\hline Taiwan & .0620 & .41081 & 1.2935 & 1.52342 & $<.001$ & .8 \\
\hline
\end{tabular}

In response to the research question, the results showed that there was a significant effect on EFL students' oral proficiency after the 6-week intervention at both sites, suggesting that the strategies applied in STELLA, including storytelling, guided reading, students' retelling, interactive discussion and structured higher-order thinking questions, not only enhance the English oral performance of ELLs in the English-speaking environment (Irby et al., 2004; Quiros, 2008; Tong et al., 2008; Quiros et al., 2012) but also are effective for EFL students' oral proficiency in nonEnglish-speaking Asian environments as well. The findings were consistent with other studies regarding the English oral language proficiency of ELLs in English-speaking environments. For example, Irby et al. (2004) reported that story reading can help ELLs acquire new vocabulary and facilitate concept development, comprehensions and narrative ability. With repeated story reading by the teacher, students can have the exposure of the language structure, fluency, prosody and listening strategies (Irby et al., 2004). Students who are exposed to repeated vocabulary reinforcement will have rapid recognition of the words and better comprehension of the text (Calderón et $a l ., 2005)$. During this process, vocabulary can also be applied and discussed in an interactive way among peers and teachers which makes learning more meaningful. Repeated reading also offers students opportunities for meaningful discussion, listening and reading practice and knowledge of first and second language acquisition (Hickman et al., 2004).

Story retelling, one of the crucial elements in STELLA, has been be considered as a form of curriculum based measurement to assess the comprehension of ELLs because it can increase the recall of discourse comprehension (Gambrell et al., 1985). For the students to retell, they must acquire enough vocabulary and construct basic story structure and along with the teacher's scaffolding, students can further acquire sophisticated language rules and oral fluency (Bauer and Arazi, 2011). Therefore, storytelling and retelling provide ELLs positive vocabulary development, higher comprehension and lower anxiety toward L2 (Uchiyama, 2011). It was evidenced that the ELLs in China and Taiwan benefited from the STELLA intervention which incorporated direct vocabulary instruction, modeling reading, leveled questioning strategy, and story retelling skills based on a meaningful learning context-through storytelling and retelling. Therefore, we conclude, based on the findings of this study, that STELLA, which is accompanied by on-going teacher training, can facilitate English oral language development among elementary ELLs in a non-English speaking environment.

In summary, although STELLA has been found to be an effective intervention to promote oral proficiency and literacy skills for ELLs when learning the second language in an English-speaking country, it had not been implemented and tested in non-English speaking areas. This pilot study is the first attempt with EFL students to test the effectiveness of STELLA. Based on this study, we provide a promising, innovative instructional alternative for EFL teachers in Asia to improve their students' English language proficiency, and we recommend future studies be conducted to evaluate STELLA at other grade levels and areas in Asia EFL settings, and for a longer duration, as well as the sustainability, together with classroom observation to further understand the teaching practice in these classrooms.

\section{References}

Anderson, V. and M. Roit, 1998. Reading as a gateway to language proficiency for language minority students in the elementary grades. In R. M. Gersten \& R.T. Jimenez (Eds). Promoting learning for culturally and linguistically diverse students: Classroom applications from contemporary research. New York: Wadsworth. pp: 42-54.

August, D., 2003. Supporting the development of english literacy in english language learners: Key issues and promising practices (ReportsDescriptive No. 61). Baltimore, MD: Center for Research on the Education of Students Placed at Risk.

Baker, C., 2006. Foundations of bilingual education and bilingualism. 4th Edn., Cleveland: Multilingual Matters.

Bauer, E. and J. Arazi, 2011. Promoting literacy development for beginning english learners. Reading Teacher, 64(5): 383-386

Calderón, M., D. August, R. Slavin, D. Duran, N. Madden and A. Gheung, 2005. Bringing words to life in classrooms with english-language learners. In E. H. Hiebert \& M. L. Kamil. (Eds). Teaching and learning vocabulary: Bringing research to practice. Mahwah, NJ: Lawrence Erlbaum. pp: 115-136.

Chen, I. and J. Hsieh, 2011. English language in Taiwan: An examination of its use in society and education in schools. In A. W. Feng (Ed). English language education across Greater China. Bristol, Buffalo, Toronto: Multilingual Matters. pp: 70-94.

Chen, S. and Y. Tsai, 2012. Research on english teaching and learning: Taiwan (2004-2009). Language Teaching, 45(2): $180-201$.

Cheng, L., 2008. The key to success: English language testing in China. Language Testing, 25(1): 15-37.

Chern, C., 2002. English language teaching in Taiwan today. Asia Pacific Journal of Education, 22(2): 97-105. DOI $10.1080 / 0218879020220209$.

Chien, Y. and Y.K. Huang, 2000. Starting with predictable stories: EFL children's oral and literacy development. Selected Papers from the Ninth International Symposium on English Teaching and Learning. Taiwan: Crane. pp: 264-273.

Collins, M.F., 1999. The use of traditional storytelling in education to the learning of literacy skills. Early Child Development and Care, 152(1): 77-108.

Collins, M.F., 2010. ELL preschoolers english vocabulary acquisition from storybook reading. Early Childhood Research Quarterly, 25(1): 8497.

Crystal, D., 2003. English as a global language. 2nd Edn., Cambridge: Cambridge University Press.

Dockrell, J.E., M. Stuart and D. King, 2010. Supporting early oral language skills for english language learners in inner city preschool provision. British Journal of Educational Psychology, 80(4): 497-515.

Domínguez, D.R.R. and E.S. Shapiro, 2007. Cross-language relationship between Spanish and english oral reading fluency among Spanishspeaking english language learners in bilingual education classrooms. Psychology in the Schools, 44(8): 795-806. DOI $10.1002 /$ pits.20266.

Elley, W., 1989. Vocabulary acquisition from listening to stories. Reading Research Quarterly, 14(2): 174-187.

Fenesi, B., F. Sana and J.A. Kim, 2014. Evaluating the effectiveness of combining the use of corrective feedback and high-level practice questions. Teaching of Psychology, 41(2): 135-143.

Feng, A., 2012. Spread of english across greater China. Journal of Multilingual and Multicultural Development, 33(4): 363-377. 
Gambrell, L.B., P.S. Koskinen and B.A. Kapinus, 1991. Retelling and the reading comprehension of proficient and less-proficient readers. Journal of Educational Research, 84(6): 356-362.

Gambrell, L.B., W.R. Pfeiffer and R.M. Wilson, 1985. The effects of retelling upon reading comprehension and recall of text information. Journal of Educational Research, 78(4): 216-220.

Gibbons, P., 2002. Scaffolding language, scaffolding learning: Teaching second language learners in the mainstream classroom. Portsmouth, NH: Heinemann.

Gibson, A., J. Gold and C. Sgouros, 2003. The power of a story retelling. Available from http://www.nationalserviceresourees.org/files/legacy/filemanager/download/learns/spr2003.pdf.

Gil, J. and B. Adamson, 2011. The english language in mainland China: A sociolinguistic profile. In A. W. Feng (Ed). English language education across greater China. Bristol, Buffalo, Toronto: Multilingual Matters. pp: 23- 45.

Government Information Office, 2002. Challenge 2008: The six-year national development plan. Taipei: Government Information Office.

Hansen, C.L., 1978. Story retelling used with average and learning disabled readers as a measure of reading comprehension. Learning Disabilities Quarterly, 1(3): 62-69.

Hickman, P., S. Pollard-Durodola and S. Vaughn, 2004. Storybook reading: Improving vocabulary and comprehension for english language learners. Reading Teacher, 57(8): 720-730.

Honna, N., 2006. East Asian englishes. In B.B. Kachru,Y. Kachru and C.L. Nelson (Eds.). The handbook of world englishes. Malden, MA: Blackwell Publishing. pp: 114-29.

Hsu, T.C., 2015. Telling tales: Using storytelling to teach EFL kindergarten students in Taiwan. International Journal of Research Studies in Education, 4(4): 13-25.

Hu, G., 2007;2008. The judgment of Chinese-english bilingual education. In A. W. Feng (Ed). Bilingual education in China: Practice, policies and concepts. Cleveland, Buffalo, Toronto: Multilingual Matters. pp: 94-126.

Hu, G. and L. Alsagoff, 2010. A public policy perspective on english medium instruction in China. Journal of Multilingual and Multicultural Development, 31(4): 365-382.

Hu, G. and S.L. McKay, 2012. English language education in East Asia: some recent developments. Journal of Multilingual and Multicultural Development, 33(4): 345-362. DOI 10.1080/01434632.2012.661434.

Irby, B.J., R. Lara-Alecio, A.M. Quiros, G.P. Mathes and L. Rodríguez, 2004. English language acquisition evaluation research program (Project ELLA): Second Annual Evaluation Report. Washington, DC: Institute for Educational Sciences, U.S. Department of Education.

Irby, B.J., A.M. Quiros, R. Lara-Alecio, L. Rodriguez and G.P. Mathes, 2008. What administrators should know about a research-based oral language development intervention for english language learners: A description of Story retelling and higher order thinking for english language and literacy acquisition--STELLA. International Journal of Educational Leadership Preparation, 3(2): 1-19.

Isbell, R.S., J. Sobol, L. Lindauer and A. Lowrance, 2004. The effects of storytelling and story reading on the oral language complexity and story comprehension of young children. Early Childhood Education Journal, 32: 157-163. DOI 0.1023/B:ECEJ.0000048967.94189.a3.

Jiang, Y., 2003. English as a Chinese language. English Today, 19(2): 3-8.

Kachru, B.B., 1986. The alchemy of english: The spread, functions and models of non-native englishes. Oxford: Pergamon.

Kamil, M., 2004. Vocabulary and comprehension instruction. In P. McCardle \& V. Chhabra (Eds). The voice of evidence in reading research. Baltimore, MD: Paul H. Brookes Publishing Co. pp: 213-234.

Lara-Alecio, R., B.J. Irby and P. Mathes, 2006. Project ELLA: English language and literacy acquisition. Paper Presented at the American Educational Research Association, San Francisco, CA.

Lara-Alecio, R., B.J. Irby and F. Tong, 2015. Professional development for teachers of ELLs in project ELLA-V (Invited Keynote). I3 Project Directors Conference. Washington, D.C.

Lara-Alecio, R., B.J. Irby, F. Tong and C. Guerrero, 2016. English language and literacy acquisition-validation: RCT district highlights. A Presentation Sponsored by the Center for Research and Development in Dual Language and Literacy Acquisition (CRDLLA) and Education Leadership Research Center (ELRC). Texas A\&M University. Retrieved from elrc.tamu.edu.

Lever, R. and M. Sénéchal, 2011. Discussing stories: On how a dialogic reading intervention improves kindergartners oral narrative construction. Journal of Experimental Child Psychology, 108(1): 1-24.

Liu, Q.X. and J.F. Shi, 2007. An analysis of language teaching approaches and methods--effectiveness and weakness. Online Submission, 4(1): 69-71.

Malderez, A., 2010. Stories in ELT: Telling tales in school. Procedia Social and Behavioral Sciences, 3: 7-13

Massey, S.L., 2013. From the reading rug to the play center: Enhancing vocabulary and comprehensive language skills by connecting storybook reading and guided play. Early Childhood Education Journal, 41(2): 125-131.

McKay, S.L. and W. Bokhorst-Heng, 2008. International english in its sociolinguistic contexts: Towards a socially sensitive EIL pedagogy. New York: Routledge.

McVey, D.C., 2007. Helping ESL students improve their vocabulary. ESL Magazine, 58: 20-21.

Miller, J.F., J. Heilmann, A. Nockerts, A. Iglesias, L. Fabiano and D.J. Francis, 2006. Oral language and reading in bilingual children. Learning Disabilities Research and Practice, 21: 30-43. DOI 10.1111/j. 1540-5826.2006.00205.

Mokhtar, N.H., M.F.A. Halim and S.Z.S. Kamarulzaman, 2011. The effectiveness of storytelling in enhancing communicative skills. ProcediaSocial and Behavioral Sciences, 18: 163-169.

Moon, J. and U. Maeng, 2012. A comparison study of the effect of reading instruction using storytelling and storysinging. Proceeding of 17th Conference of Pan-Pacific Association of Applied Linguistic. School of Education, Ajou University.

Morrow, L.M., 1996. Story retelling: A discussion strategy to develop and assess comprehension. In L. B. Gambrell \& J. F. Almasi (Eds) Lively discussions! fostering engaged reading. Newark, DE: International Reading Association. pp: 265-285.

Ovando, C. and V. Collier, 1998. Bilingual and ESL classrooms: Teaching in multicultural context. New York: McGraw Hill.

Pan, L. and D. Block, 2011. English as a global language in China: An investigation into learners and teachers language beliefs. System: An International Journal of Educational Technology and Applied Linguistics, 39(3): 391-402.

Peck, J., 1989. Using storytelling to promote language and literacy development. Reading Teacher, 43(2): 138-141.

Quiros, A.M., 2008. Structured story reading and retell related to listening comprehension and vocabulary acquisition among English language learners. Retrieved from ProQuest. DAI-A 69/10, Dissertation Abstracts International.

Quiros, A.M., R. Lara-Alecio, F. Tong and B.J. Irby, 2012. The effect of a structured story reading intervention, story retelling and higher order thinking for english language and literacy acquisition. Journal of Research in Reading, 35(1): 87-113.

Raines, S. and R. Isbell, 1994. Stories: Children's literature in early education. Albany, NY: Delmar.

Reese, L., H. Garnier, R. Gallimore and C. Goldenberg, 2000. Longitudinal analysis of the antecedents of emergent Spanish literacy and middle-school english reading achievement of Spanish-speaking students. American Educational Research Journal, 37(3): 633-662.

Roberts, G., R. Good and S. Corcoran, 2005. Story retell: A fluency-based indicator of reading comprehension. School Psychology Quarterly, 20: 304-317. DOI 10.1521/scpq.2005.20.3.304.

Roberts, T., 2008. Home storybook reading in primary or second language with preschool children: Evidence of equal effectiveness for secondlanguage vocabulary acquisition. Reading Research Quarterly, 43(2): 103-130.

Roney, R.C., 1996. Storytelling in the classroom: Some theoretical thoughts. Storytelling World, 9: 7-9.

Saenz, L.M., L.S. Fuchs and D. Fuchs, 2005. Peer-assisted learning strategies for english language learners with learning disabilities. Exceptional Children, 71(3): 231-247.

Saunders, W. and G. O'Brien, 2006. Oral language. In F. Genesse, K. Lindholm-Leary, W. M. Saunders and D. Christian (Eds). Educating english language learners: A synthesis of research evidence. New York: Cambridge University Press. pp: 14-63.

Slavin, R. and A. Cheung, 2005. A synthesis of research on language of reading instruction for english language learners. Review of Educational Research, 75(2): 247-284. 
Slavin, R.E. and N.A. Madden, 1999. Success for all roots \& wings: 1999 summary of research on achievement outcomes. Baltimore: Johns Hopkins University, Center for Research on the Education of Students Placed at Risk.

Smith, C. and D. Ellis, 2003. Oral language development as a precursor to literacy. Washington, DC: Institute of Education Sciences.

Snow, C., 2002. Reading for understanding: Toward an R \& D program in reading comprehension. Santa Monica, CA: Rand.

Snow, C., M. Burns and P. Griffin, 1998. Preventing reading difficulties in young children. Washington, D.C: National Academy Press.

Sobol, J.D., 1992. Innervision and innertext: Oral traditional and oral interpretive modes of story performance. Oral Tradition, 7(1): 66-86.

$\mathrm{Su}, \mathrm{F} ., 2000$. New goal orientation of english teaching for young EFL learners. Conference of ELT Curriculum for Young Learners in East Asia 2000. Taipei, Taiwan.

Tong, F., R. Lara-Alecio, B.J. Irby, P. Mathes and O. Kwok, 2008. Accelerating early academic oral english development in transitional bilingual and structured english immersion programs. American Educational Research Journal, 45(4): 1011-1044. DOI 10.3102/0002831208320790.

Tupas, T., 2011. English-knowing bilingualism in Singapore: Economic pragmatism ethnic relations and class. In A. W. Feng (Ed). English language education across greater China. Bristol, Buffalo, Toronto: Multilingual Matters. pp: 46-69.

Uchiyama, T., 2011. Reading versus telling of stories in the development of english vocabulary and comprehension in young second language learners. Reading Improvement, 48(4): 168-178.

Walichowski, M., 2009. An alternative oral proficiency and expressive vocabulary assessment of kindergarten english language learners. (Order No. 3399912, Texas A\&M University). ProQuest Dissertations and Theses, 279-n/a. Available from http://libezproxy.tamu.edu:2048/login?url=http://search.proquest.com/docview/305117825?accountid=7082.(305117825.

Zhang, W., 2012. A brief introduction to foreign languages education policy in China: Online Submission. Available from http://www.eric.ed.gov/contentdelivery/servlet/ERICServlet?accno=ED530281.

\section{Bibliography}

Farrell, C.H. and D.D. Nessell, 1982. The effects of storytelling: An ancient art for modern classrooms (Report No. ISBN-0-936434-04-X). San Francisco, CA.

$\mathrm{Hu}, \mathrm{G} ., 2005$. English language education in China: Policies, progress, and problems. Language Policy, 4(1): 5-24.

Kame'enui, E., M. Adams and R. Lyon, 1996. Learning to read/reading to learn. Washington, D.C: US Department of Education.

Lara-Alecio, R., B.J. Irby and G.P. Mathes, 2003. English language and literacy acquisition (Project ELLA). Washington, D.C: U.S. Department of Education.

Schellenberg, R. and T. Grothaus, 2009. Promoting cultural responsiveness and closing the achievement gap with standards blending. Professional School Counseling, 12(6): 440-449.

Tong, F., 2006. Oral english development and its impact on emergent reading achievement: A comparative study of transitional bilingual and structured english immersion models Order No. 3296556. ProQuest Dissertations \& Theses Global. 304930019. Available from http://lib-ezproxy.tamu.edu:2048/login?url=http://search.proquest.com/docview/304930019?accountid=7082. 